\title{
外壁性能試験装置を用いた実験による壁体吸放湿量簡易計算法の精度検証 多数室温湿度計算への適用を目的とした室内表面の吸放湿計算モデル その 2 \\ ACCURACY VERIFICATION OF SIMPLIFIED CALCULATION METHOD FOR MOISTURE SORPTION WITH EXTERNAL WALL PERFORMANCE TEST HOUSE
}

Simplified numerical model of moisture transfer on interior surfaces for transient room temperature and heat load calculation of multiple zone buildings Part 2

\section{細川隆行*, 林徹夫**, 好村純一*** Takayuki HOSOKAWA, Tetsuo HAYASHI and Junichi YOSHIMURA}

\begin{abstract}
Detailed equations of combined heat and moisture transfer have been proposed to analyze temperature and humidity fluctuation of walls. They are, however, too complicated to apply to transient room temperature and heat load calculation of multiple zone buildings. Therefore, we proposed a simplified calculation method for sorption on walls. It is necessary to confirm the predictive accuracy of the indoor humidity when the simplified calculation method is applied. This paper describes that the indoor humidity fluctuation model applied the proposed calculation method, and the predictive accuracy of the model is confirmed by the comparison with the experiment. The experiment was carried out in the model house where the building materials to regulate an indoor humidity was set up. The measurement and calculation values were agreed and the effectiveness of the simplified calculation method was shown.
\end{abstract}

Keywords: Simplified Calculation Method, Adsorption and Desorption, Inside of Walls, Indoor Humidity, Experiment 簡易計算法，吸放湿，壁体内表面，室内湿度，実験

\section{1. はじめに}

室内には壁体，家具，衣類など吸放湿する材料が多数存在するた め，その温湿度環境を十分な精度で予測評価するには，これら吸放 湿材の影響を考慮する必要がある。一方で年間を通した室内温湿度 環境や熱負荷の予測では，壁体を一次元伝熱，室内空気の瞬時一様 拡散を仮定した汎用室温変動熱負荷シミュレーションが用いられる。 汎用室温変動熱負荷シミュレーションでは, 室内空気温度および熱 負荷の変動の解析に重点が置かれ, 室内湿度変動における吸放湿現 象は簡略化して取り扱うことが多い。すなわち, 仮想の潜熱 (水分) 容量を室内空気に付与し, 吸放湿の影響を擬似的に考慮している ${ }^{1)} 。$ 壁体の吸放湿を考慮した室内湿度の解析には, 絶対湿度をポテン シャルとした手法が多い 2)-6)。また他の指標をポテンシャルとする 方法を含めても壁体内部の湿気移動まで考慮されることがほとんど である。このため, 上記の解析手法を既存の汎用室温変動熱負荷シ ミュレーションに適用する場合に, 計算体系の見直しが必要になる こともある(例えば, 壁体熱伝導に逐次積分法 ${ }^{7}$ を用いている場合)。 そこで筆者らは既報 ${ }^{8)}$ において, 既存の室温変動熱負荷シミュレ ーションへの付加を考慮し, 室内空気温度および室内表面温度を既 知として，室内表面の吸放湿量を算定する簡易計算法（以下，簡易 法）を提案した。簡易法は, 壁体表面近傍層（水分容量層）と室内 空気間の水分ポテンシャル差を駆動力とする物質伝達による水分収
支を考元, 水分容量層内の水分ポテンシャル分布を, 水分ポテンシ ヤル勾配を有する部分（水分伝導層注 ${ }^{11}$ ) と水分ポテンシャルが均一 な部分からなる折れ線で近似できると仮定する。

既報では，自然室温を仮定した室内温湿度変動に対して，計算時 間間隔 1 時間の簡易法と 5 分間の熱・水分複合移動方程式による計 算（以下，詳細法）の壁体吸放湿量を比較した。その結果，簡易法 が実用上，十分な計算精度を有することを示した。

熱・水分複合移動方程式は，既往の研究により実測および実験に よる測定值との比較が行われ，モデルの妥当性が十分に確認されて いる。しかし，既報の数值計算による簡易法の精度の検証は，壁体 単位の計算結果の比較にすぎず，室単位での計算で簡易法が不整合 を生まないことを確認する必要がある。また，前報で仮定した室内 温湿度変動は自然状態であり, 除湿器や加湿器の運転開始時のよう な, 短時間で大きな室内湿度変動が生じたときの計算精度も確認す る必要がある。そこで本報では, 内装材として調湿建材を設置した 外壁性能試験装置 (以下, 実験家屋と称す) 内の湿度変動を測定し, その結果と壁体吸放湿量算定に簡易法を用いた室内湿度変動モデル による計算結果の比較により，簡易法の実用性について検討する。 調湿建材には「繊維混入珪酸カルシウム板(バーミキュライト入り)」 （以下，バーミキュライト建材と称す）を使用する。

既報で示した簡易法を用いて，室内湿度を求める方法の一例を以

\footnotetext{
* 東芝キヤリア侏) 博士 (工学)

** 九州大学大学院総合理工学研究院 教授. 工博

*** 九州大学大学院総合理工学府 大学院生
}

Toshiba Carrier Co., Dr. Eng.

Prof., Faculty of Engineering Science, Kyushu Univ., Dr. Eng.

Graduate Student, Interdisciplinary Graduate School of Engineering Sciences, Kyushu Univ. 
下に示す。簡易法は蒸発（凝縮）潜熱など，水分の熱伝導への影響 を無視しているため, 室温計算と室内湿度計算を分離して計算でき る。従って, 以下の説明では温度を既知量として取り扱う。室内空 気の瞬時一様拡散性を仮定すれば, 室内空気の水分収支は, 室 $i$ の 絶対湿度を $X_{i}$ とすれば, $X_{i}$ に関する一階常微分方程式として, 式(1) で表される。

$$
\begin{aligned}
\rho_{i} V_{i} \frac{d X_{i}}{d t}= & \sum_{i j=1}^{I} G_{i j}\left(X_{i j}-X_{i}\right)+G_{o}\left(X_{o}-X_{i}\right) \\
& +W_{i}+G_{a c, i}\left(X_{a c}-X_{i}\right)+\sum_{j=1}^{J} S P_{j} S_{j}
\end{aligned}
$$

第 1 項, 第 2 項は室 $i$ の隣室 $i j$ や外気 $o$ との換気による水蒸気移 動量, 第 3 項は室 $i$ での室内水蒸気発生量, 第 4 項は冷房機による 除湿量, 第 5 項は室内表面 $j$ における吸放湿量を表す。 $\rho_{i}$ は室 $i$ の乾

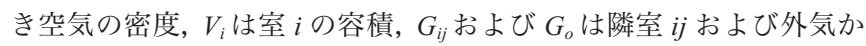
ら流入する空気の重量流量, $W_{i}$ は室内水蒸気発生量, $G_{a c, i}$ は室 $i$ に 設置された冷房機吹出空気の重量流量, $S P_{j}$ および $S_{j}$ は室内表面 $j$ の単位表面積あたりの吸放湿量および表面積である。提案した簡易 方を用いれば， $S P_{j}$ は次式となる。

$$
S P_{j}=\frac{1}{\frac{1}{\alpha_{j}^{\prime}}+\frac{M_{j}}{\lambda_{j}^{\prime}}}\left(\mu_{w, j^{\prime}}-\mu_{w, i}\right)
$$

ここで, $\alpha_{j}^{\prime}, \lambda_{j}^{\prime}, M_{j}$ は室内表面 $j$ の水分伝達率, 気相水分伝導率, 水分伝導層の厚みである。また, $\mu_{w, j}$ は室内表面 $j$ の水分容量層内部 の水分ポテンシャルであり, $\mu_{w, i}$ は室 $i$ の空気の水分ポテンシャルで ある。式(2)を式(1)に代入すると, 水分ポテンシャルと絶対湿度は非 線形関係注 ${ }^{2)}$ にあるため, 式(1)は非線形方程式となる。従って, 反 復計算により解を得る必要がある。

室内絶対湿度 $X_{i}$ を一旦既知量として, 室 $i$ に存在し吸放湿が発生 する全ての表面において既報 ${ }^{8}$ の式(21)を解き, 水分容量層内の水分 ポテンシャル $\mu_{w, j}$ を求め, 式(2)より吸放湿量 $S P_{j}$ を算出する。そして, 式(1)より室内絶対湿度 $X_{i}$ の計算し, 得られた $X_{i}$ から再度壁体吸放 湿 $S P_{j}$ を求めるという反復計算を行う。反復計算の収束条件は室内 湿度 $X_{i}$ の変化量が十分小さくなるまでとする。

\section{2. 実験の概要}

\section{1. 実験設備と測定の概要}

実験は福岡県春日市にある九州大学筑紫キャンパス $\mathrm{F}$ 棟屋上に設 置された実験家屋で行った。実験家屋の平面図と断面図を図 1 , 図 2 に示す。実験家屋は居室および前室, これらの室の空調設備が設置 されている機械室の 3 室で構成される。実験では前室のドアを開放 し, 前室は外気と同等とみなし, 居室を測定対象とする。居室の床 面積は $3.24 \mathrm{~m}^{2}$, 容積は $8.1 \mathrm{~m}^{3}$ である。実験家屋は居室部外壁の一部

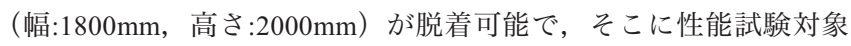
の外壁を設置できる。居室と前室の隔壁はアルミハニカムパネル(厚 さ $42 \mathrm{~mm}$ ) である。従って, 居室部外壁以外の壁体表面では吸放湿 が生じない。実験では外壁に, 室内側からバーミキュライト建材 (厚 さ $6 \mathrm{~mm}$ ), アルミ箔, 非密閉中空層, 合板 (厚さ $12 \mathrm{~mm}$ ), 防水シー トで構成される壁体を取り付けた。さらに居室の吸放湿量を多くす

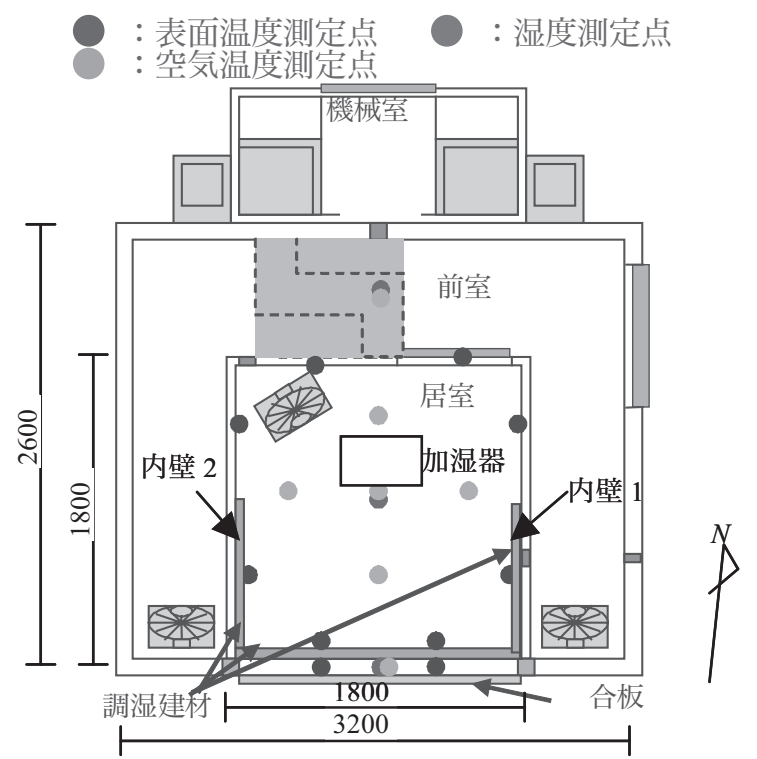

図 1 実験室平面図と測定位置

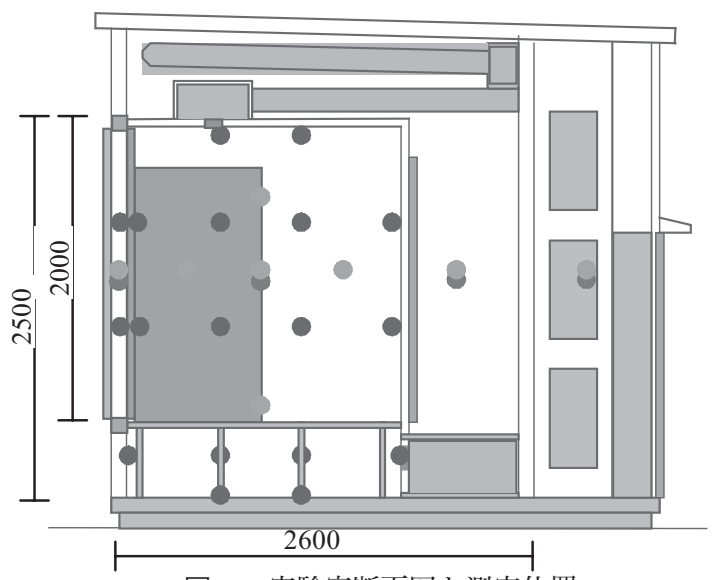

図 2 実験室断面図と測定位置

るために, 内壁に裏面をアルミ箔とアルミテープで断湿したバーミ キュライト建材（幅:900mm，高さ:1800，厚さ:6mm）を付設した。 居室空気に接するバーミキュライト建材の表面積は合計で $6.84 \mathrm{~m}^{2}$ である。居室内空気に温湿度分布が生じないよう, 室内にファンを 設置し, 室内空気を摚汼した。居室の空調は, 実験では使用しない ため, 居室の空調機吹出および吸込口をポリエチレンフィルムで塞 ぎ，機械室からの水蒸気流入を防止した。居室の換気量は，実験終 了後に $\mathrm{SF}_{6}$ ガスを用いた濃度減衰法 ${ }^{11)}$ にり測定した。その結果, 居室の換気回数は 0.6 回 $/ \mathrm{h}\left(\right.$ 換気量 $\left.4.86 \mathrm{~m}^{3} / \mathrm{h}\right)$ であった。さらに居室 のドア周りの隙間を防湿シートやテープで塞いで測定したところ, 換気回数は 0.07 回 $/ \mathrm{h}$ (換気量 $0.567 \mathrm{~m}^{3} / \mathrm{h}$ ) であり, 外壁から居室への 換気量よりも居室と前室間の換気量が多い。

図 1, 図 2 に主な測定点を示す。温度は $\mathrm{T}$ 熱電対, 相対湿度は静 電容量式薄膜湿度計 (VISALA 社製) を使用する。室内空気温度は, 居室が鉛直方向に 3 点, 水平方向に 5 点, 前室および外壁中空層で は 1 点を測定する。また, 壁体表面温度は天井と床面が各 4 点, そ の他の壁は上下方向 3 点, 水平方向 2 点の計 6 点, 外壁および隔壁 に付設したバーミキュライト建材は上下に 2 点を測定する。相対湿 度は居室, 前室, 機械室, 外壁中空層の中央に各 1 点を測定する。 測定時間間隔は 1 分間で, 測定期間は 2007 年 12 月 12 日〜 15 日の 4 
日間である。 3 日目の午前まで 8 時と 20 時（計 5 回）に居室内を加 湿器により加湿する。加湿量は電子上皿天科で加湿器重量を測定し, その減少量から求めた。加湿時間は, 本研究では 1 時間程度の計算 時間間隔を対象とするため, 1 時間以上を目標とした。ただし, 結 露が生じないよう, 居室の相対湿度が $90 \%$ になるまでしし。

\section{2. 調湿材の湿気物性值}

計算に必要なバーミキュライト建材の気相水分伝導率および水分 容量を測定した。測定用試料は，実験に用いるバーミキュライト建 材の一部を切り出したものである。

気相水分伝導率はカップ法 ${ }^{12)}$ と同じ原理により測定する ${ }^{9)}$ 。試料 2 個の測定結果の平均值は $1.070 \times 10^{-13} \mathrm{~kg} /(\mathrm{m} \cdot \mathrm{s} \cdot(\mathrm{J} / \mathrm{kg}))$, 偏差は $\pm 0.099 \times 10^{-13} \mathrm{~kg} /(\mathrm{m} \cdot \mathrm{s} \cdot(\mathrm{J} / \mathrm{kg}))$ であった。

水分容量は窒素ガス吸着法により得られる細孔径分布よりょもと めた。図 3 に窒素ガス吸着法 ${ }^{13)}$ により得られたバーミキュライト建 材の細孔径分布を示す。細孔半径が $1 \mathrm{~nm}$ で最も細孔容積が大きい。 これは細孔半径の測定範囲が半径 $1 \mathrm{~nm}$ 未満を対象としていないた め, 細孔半径 $1 \mathrm{~nm}$ 未満のすべての細孔容積を測定したと思われる。 図 4 に細孔径分布から計算した容積基準容積含水率と不飽和水分 ポテンシャルの関係（ $\phi-\mu$ 関係）を示す。図中の相対湿度は，温度 $23^{\circ} \mathrm{C}$ 時の相対湿度である。液水が細孔半径の小さい毛細管から保水 されると仮定すると，ある状態の体積含水量は 0 からある細孔半径 $r$ までの空隙容積 $v(r)$ の積算值で表される。従って, 容積基準容積 含水率 $\phi$ は, 式(3)上り求められる。式(3)と図 3 から細孔半径と容積 基準容積含水率の関係が得られる。また，不飽和水分ポテンシャル と細孔半径の関係は式(4)に示す Kelvin 式 ${ }^{13)}$ にり得られる。細孔 半径と容積基準容積含水率の関係に, 式(4)を適用すれば， $\phi-\mu$ 関係 （図 4) が得られる。

$$
\begin{aligned}
& \phi=\rho_{0} \int_{0}^{r} v(r) d r \\
& \mu=R_{v} T \ln \left(\frac{p_{v}}{p_{s}}\right)=-\frac{2 \sigma_{l w}}{r \rho_{l w}} \cos \theta_{l w}
\end{aligned}
$$

ここで， $\rho_{0}$ は絶乾時の材料密度 $\left(830 \mathrm{~kg} / \mathrm{m}^{3}\right), \rho_{l w}, \sigma_{l w}, \theta_{l w}$ は液水 の密度 $\left(998 \mathrm{~kg} / \mathrm{m}^{3}\right)$, 表面張力 $(72.3 \mathrm{mN} / \mathrm{m})$, メニスカスの接触角で ある。メニスカスの接触角は $0^{\circ}$ を仮定した ${ }^{10)}$ 。

水分容量は $\phi-\mu$ 関係の接線の勾配に液水の密度を乗じたものと して表される注3)。簡易法では気相水分伝導率 $\lambda_{g}{ }_{g}$ と水分容量 $\rho_{l w} \partial \phi / \partial \mu$ から式(5)および式(6)を用いて, 水分容量層の厚み $L$ と水分伝導層の 厚み $M$ を決定する。

$$
\begin{aligned}
& L=335.0\left\{\lambda_{g}^{\prime} /\left(\rho_{l w} \frac{\partial \phi}{\partial \mu}\right)\right\}^{0.53} \\
& M=234.0\left\{\lambda_{g}^{\prime} /\left(\rho_{l w} \frac{\partial \phi}{\partial \mu}\right)\right\}^{0.55}
\end{aligned}
$$

図 5 に, 相対湿度 $\left(\right.$ 温度 $\left.23^{\circ} \mathrm{C}\right)$ と $L, M$ の関係を示す。バーミキ ュライト建材内の相対湿度が約 $60 \%$ を下回ると $L$ が，さらに約 $35 \%$ を下回ると $M$ が，実験に使用する建材の厚み $6 \mathrm{~mm}$ を上回る。図 4

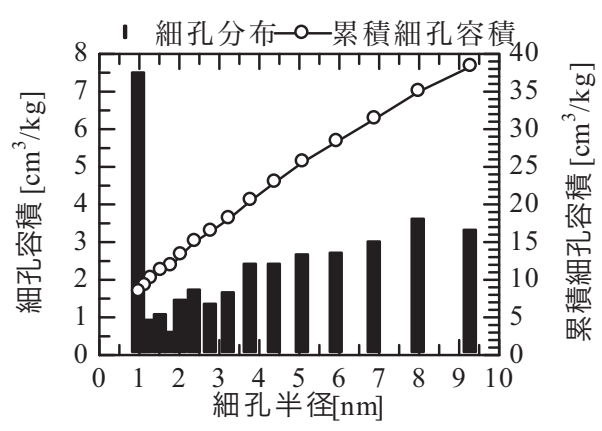

図 3 細孔径分布

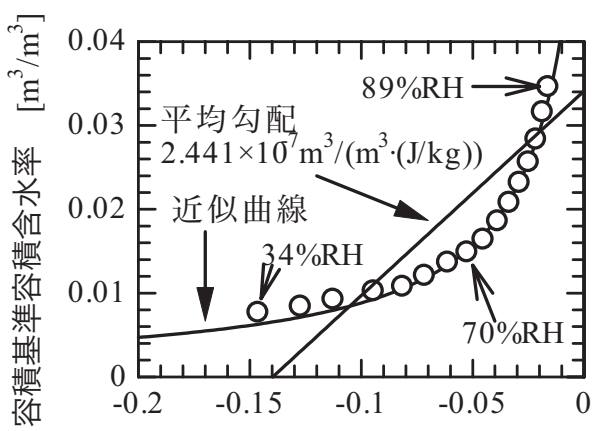

不飽和水分ポテンシャル[MJ/kg]

図 4 容積含水率と不飽和水分ポテンシャルの関係

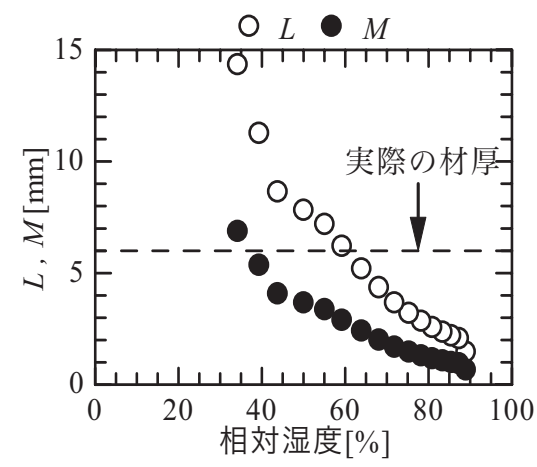

図 5 水分容量層および水分伝導層の厚み

より, バーミキュライト建材の水分容量は相対湿度 $70 \%$ (温度 $23^{\circ} \mathrm{C}$ のとき）付近で大きく変化するため，既報のように $L, M$ に一定值 を仮定することは難しい。しかし，時刻毎に $L$ を計算すると，気相 水分の質量平衡が保証されなくなる。そこで $L$ は，気相水分の拡散 係数の平均值 $2.44 \times 10^{-4} \mathrm{~kg} /\left(\mathrm{m}^{3} \cdot(\mathrm{J} / \mathrm{kg})\right.$ ) (図 4 参照) から求めた $L=$ $3.68 \mathrm{~mm}, M=1.68 \mathrm{~mm}$ とする。

\section{3. 実験結果と簡易法の計算精度の検証}

\section{1. 実験結果}

図 6 にバーミキュライト建材の居室内側平均表面温度を示す。ま た, 図 7 に居室, 前室, 外壁中空層の空気温度変動を示す。居室内 空気温度は測定した 7 点の平均值である。計測期間中の空気温度分 布の最大偏差は $0.4 \mathrm{~K}$ 程度であり, 居室内空気は十分に攪汼されてお り, 温度分布は小さい。また，室内をファンで覺拌していることを 踏まえれば，湿度分布も小さいものと考える。相対湿度変動を図 8 


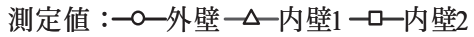

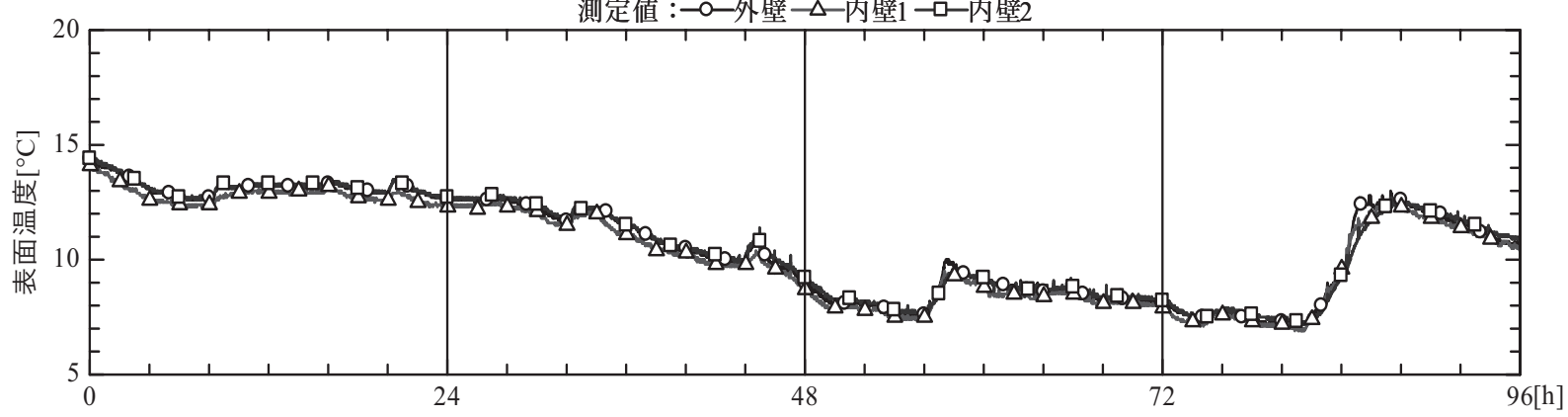

図 6 壁体表面温度

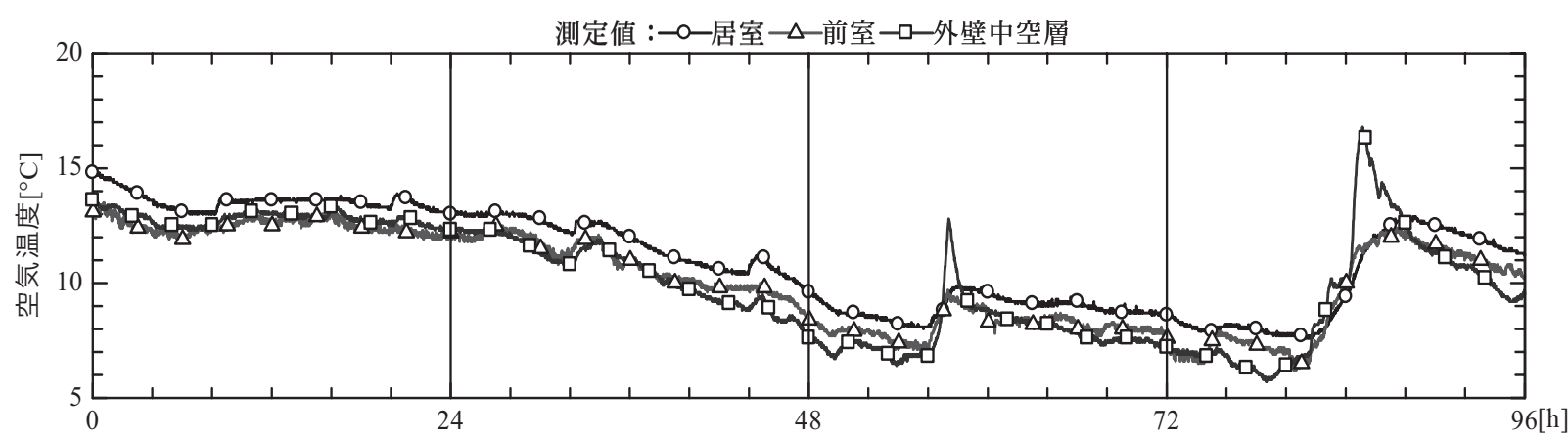

図 7 室内空気温度

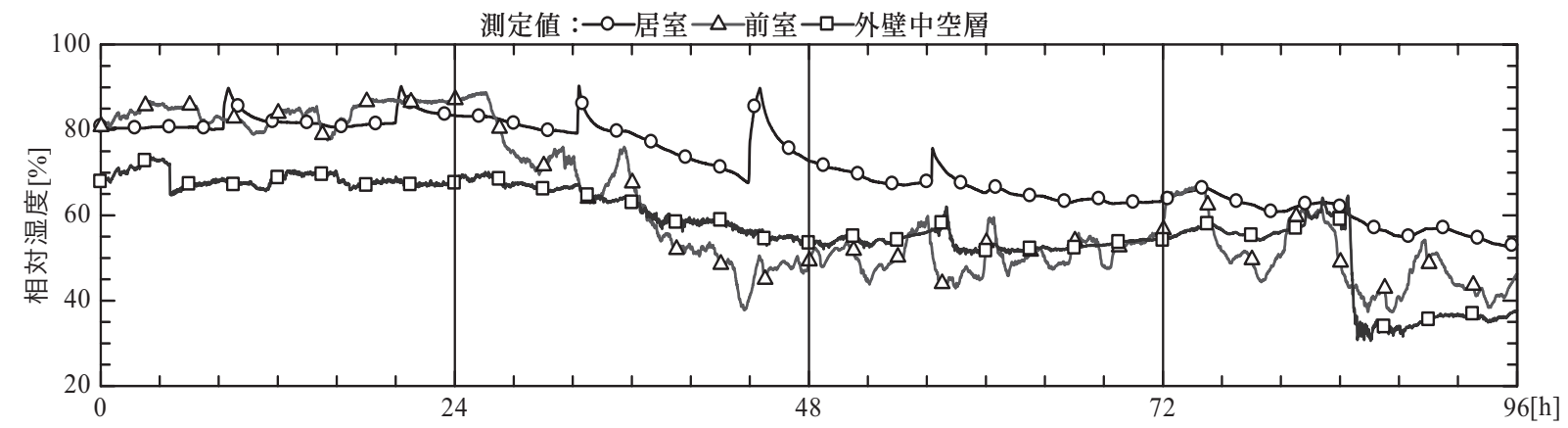

図 8 相対湿度変動

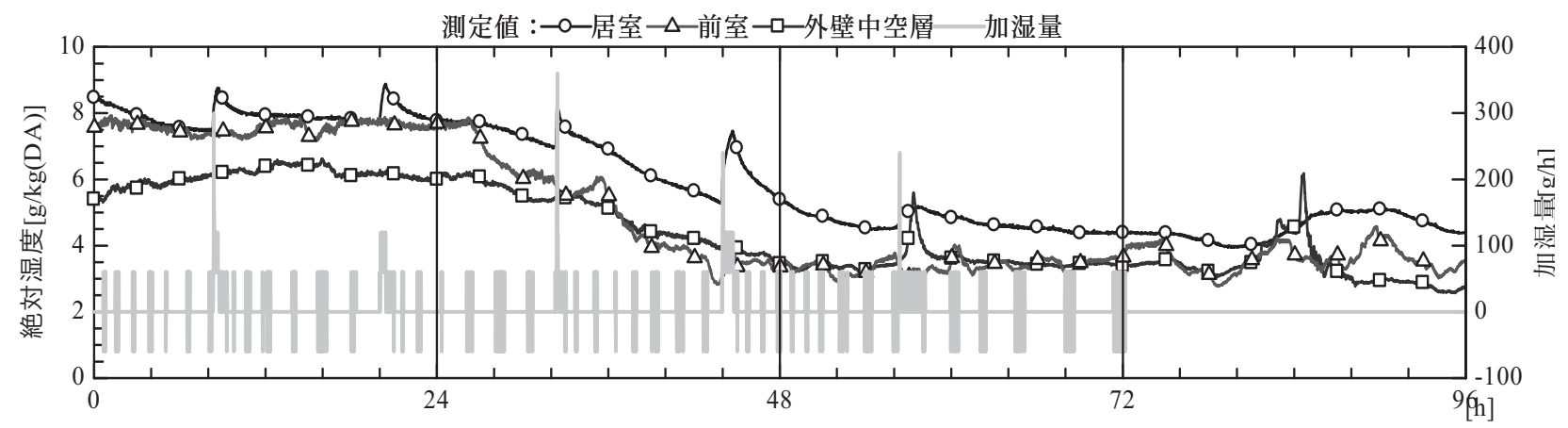

図 9 絶対湿度変動と加湿量

を示す。また, 絶対湿度変動と加湿量を図 9 に示す。実験初日の居 室および前室の相対湿度が $80 \%$ 前後と高くなっているが，これは実 験開始前後の降雨のためである。加湿時間は目標である 1 時間を概 ね満足している。加湿量に負の值があるのは, 室内空気を擋拌する ファンの風圧によるものと思われる。

\section{2. 計算条件}

室内湿度変動モデルへの入力は, 居室の空気温度, バーミキュラ イト建材の表面温度, 前室および外壁中空層の相対湿度, 居室の換
気量の測定值である。出力は, 居室の湿度である。換気による水蒸 気移動は居室と前室, 居室と外壁中空層の 2 経路が存在するため, 測定した換気量の $90 \%$ が前室から, 残り $10 \%$ が外壁中空層から流入 すると仮定する。また, 加湿量は, 加湿器運転中については測定デ 一夕を計算の入力値とし, 非運転中は加湿器からの水分蒸発量は少 ないため無視する。

壁体吸放湿を考慮し, 熱・水分複合移動方程式（以下，詳細法） または簡易法を適用した場合，壁体吸放湿を無視した場合の三者を 
比較する。計算時間間隔は測定と同じ 1 分間とする。また, 壁体吸 放湿を考慮する場合については，年間のエネルギー消費量算定でよ く用いられる計算時間間隔を 1 時間とした場合も計算する。

詳細法は建材を 7 分割し, Crank-Nicolson 陰解法により計算する。 バーミキュライト建材表面温度を境界条件に, 蒸発潜熱の影響を無 視して温度分布を求め, バーミキュライト建材裏面断湿条件におい て水分収支を解く。

壁体吸放湿を考慮した場合のバーミキュライト建材内の初期含水 率と建材表面, 室内空気間分伝達率は，詳細法を用いた場合の居室 内湿度の計算值と測定值が最も良く一致するように設定する。具体 的には初期含水率が相対湿度 $85 \%$ と平衡する含水率, 水分伝達率は 対流熱伝達率 $\alpha_{c}$ が $8 \mathrm{~W} /\left(\mathrm{m}^{2} \cdot \mathrm{K}\right)$ であるとし, 式(7)の Lewis の関係より 対流熱伝達率 $\alpha_{c}$ から絶対湿度基準の水分伝達率 $\alpha_{X}^{\prime}$ を求め, 式(8)に より水分ポテンシャル基準の水分伝達率 $\alpha^{\prime}$ に変換した值である。

$$
\begin{aligned}
& \alpha_{X}^{\prime}=\frac{\alpha_{c}}{c_{p, m}} \\
& \alpha^{\prime}=\alpha_{X}^{\prime} \frac{\partial X}{\partial \mu}=\alpha_{X}^{\prime} \frac{\partial X}{\partial p} \frac{\partial p}{\partial \mu}=\alpha_{X}^{\prime}\left\{\frac{\frac{m_{v}}{m_{a}} R_{v} T}{X\left(X+\frac{m_{v}}{m_{a}}\right)}\right\}
\end{aligned}
$$

ここで $c_{p, m}$ は湿り空気の比熱 $(1.005+1.846 X \mathrm{~kJ} /(\mathrm{kg} \cdot \mathrm{K})), m_{v}$ は水の 分子量 $(18.02 \mathrm{~g} / \mathrm{mol}), m_{a}$ は空気の平均分子量 $(28.97 \mathrm{~g} / \mathrm{mol})$ である。

\section{3. 測定値と計算值の比較}

図 10 に測定值, 吸放湿を無視した計算, 詳細法の計算結果の比 較を示す。凡例の詳細法の括弧内は換気回数を表す。詳細法の計算 時間間隔は 1 分である。壁体の吸放湿を無視し, 換気による水蒸気 移動のみによって居室の湿度変動を予測した場合，加湿の影響で相 対湿度が $100 \%$ RH を超え, 測定值に比べ非常に大きな湿度変動が生

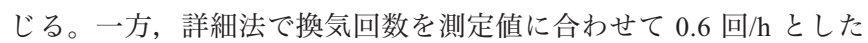
場合，2 日目の午後から測定值ほど絶対湿度が低下せず，時間がた つにつれ誤差が大きくなる。4 日目には最大で $0.8 \mathrm{~g} / \mathrm{kg}(\mathrm{DA}) の$ 䛊差が 生じる。この誤差の原因は, 図 8 , 図 9 より 2 日目以降, 前室湿度 が大きく低下し, 測定值の居室内湿度と前室湿度の差が大きくなっ ていることから，換気回数の測定誤差によるものと考えられる。そ
こで, 詳細法の計算において換気回数を 0.8 回/h（換気経路による 換気量の割り振りは同じ）とすると, 図 10 に示すように測定值と 詳細法の結果はよく一致する。換気量測定の際に前室から居室への $\mathrm{SF}_{6}$ ガスの逆流があったと思われる。以降は換気回数を 0.8 回 $/ \mathrm{h} と し$

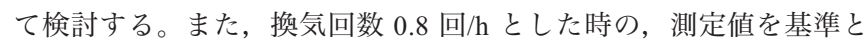
する測定期間中の詳細法の根平均二乗誤差と最大絶対誤差はそれぞ れ，相対湿度で $0.2 \% \mathrm{RH}, 5.3 \% \mathrm{RH}$, 絶対湿度で $0.02 \mathrm{~g} / \mathrm{kg}(\mathrm{DA})$, $0.43 \mathrm{~g} / \mathrm{kg}(\mathrm{DA})$ である。

次に簡易法および詳細法と測定值を比較し，簡易法の計算制度に ついて検討する。図 11 に居室の絶対湿度変動の測定值と計算值の 比較を示す。同様に図 12 に相対湿度変動の比較を示す。凡例の簡 易法の括弧内は計算時間間隔を示す。また, 詳細法は, 計算時間間 隔 1 分の結果を示す。詳細法で, 計算時間間隔を 1 時間とした場合 は, 加湿時に反復計算が収束せず解が得られなかった。

図 11, 図 12, より, 簡易法はおおむね測定值および詳細法の計 算結果と一致している。簡易法で計算時間間隔を 1 分とした場合と 測定值の根平均二乗䛊差と最大絶対誤差はそれぞれ, 相対湿度で $3.6 \% \mathrm{RH}, 12.3 \% \mathrm{RH}$, 絶対湿度で $0.30 \mathrm{~g} / \mathrm{kg}(\mathrm{DA}), 1.10 \mathrm{~g} / \mathrm{kg}(\mathrm{DA})$ である。 最大䛊差は計算時間間隔 1 分の場合は 2 日目午後の加湿時に生じる。 また計算時間間隔を 1 分とした時と測定值の根平均二乗誤差と最大 絶対誤差は, 相対湿度で $3.5 \% \mathrm{RH}, 8.5 \% \mathrm{RH}$, 絶対湿度で $0.29 \mathrm{~g} / \mathrm{kg}(\mathrm{DA})$, $0.76 \mathrm{~g} / \mathrm{kg}(\mathrm{DA})$ である。最大誤差は 4 日目の午後に生じる。いずれの 計算時間間隔においても 3 日目の午後から 4 日目にかけて測定值よ りも湿度が低くなる傾向がみられる。これは実際には長期間の多湿 状態により内装材内部まで高含水率になり, 室内湿度低下に伴う放 湿の際も, 水分が壁体内部から表面に供給されるのに対し, 簡易法 では, 壁体内部との水分移動を無視しているため水分容量層内が低 含水率化しているためと考えら机る。このことは, 長期間低湿度状 態が続く場合には，実際よりも室内湿度が高く計算されることを示 唆している。従って, 簡易法は一日以上にわたり, 室内が高湿度あ るいは低湿度になった場合に予測誤差が大きくなる。また, 計算時 間間隔を 1 分とした場合の簡易法は加湿時および加湿停止時など室 内湿度が突変した場合の予測誤差が大きくなる。ただし, 計算時間 間隔 1 時間の場合は, この傾向は緩和される。従って, 簡易法は計 算時間間隔 1 時間程度の計算に適用することが望ましい。

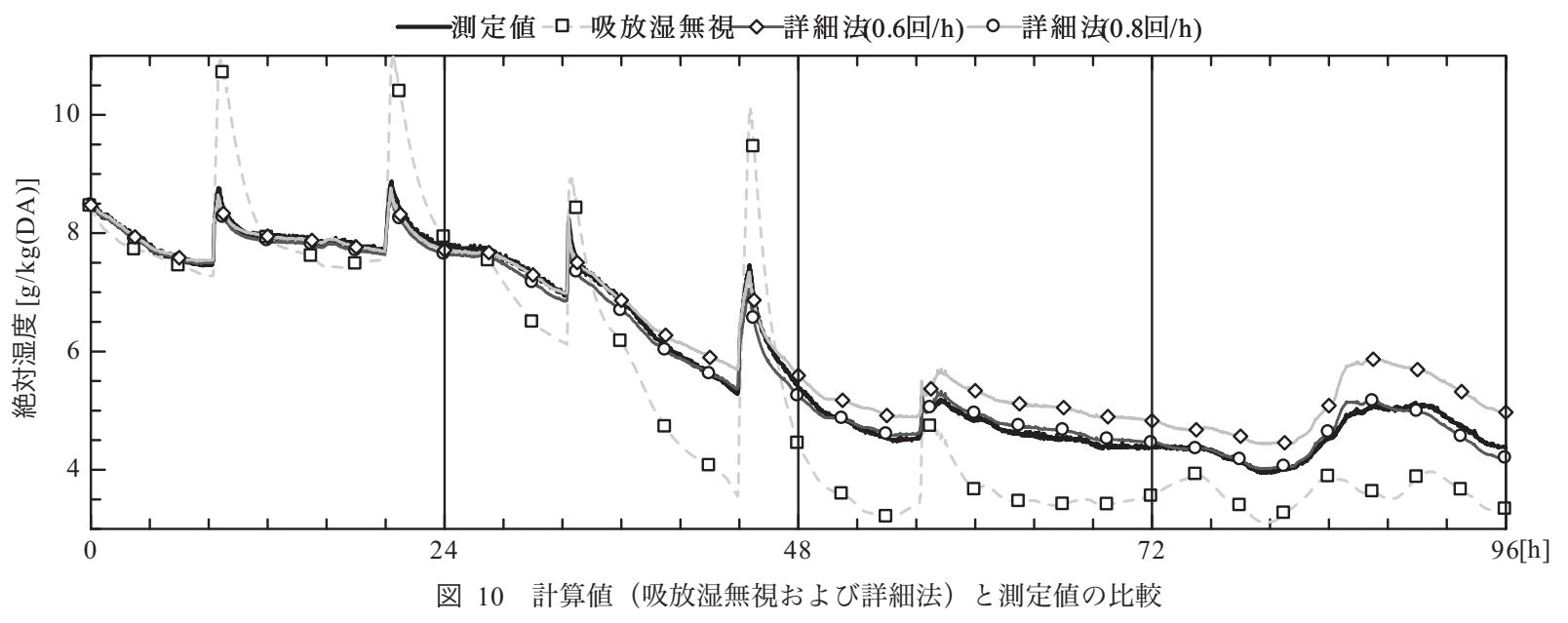




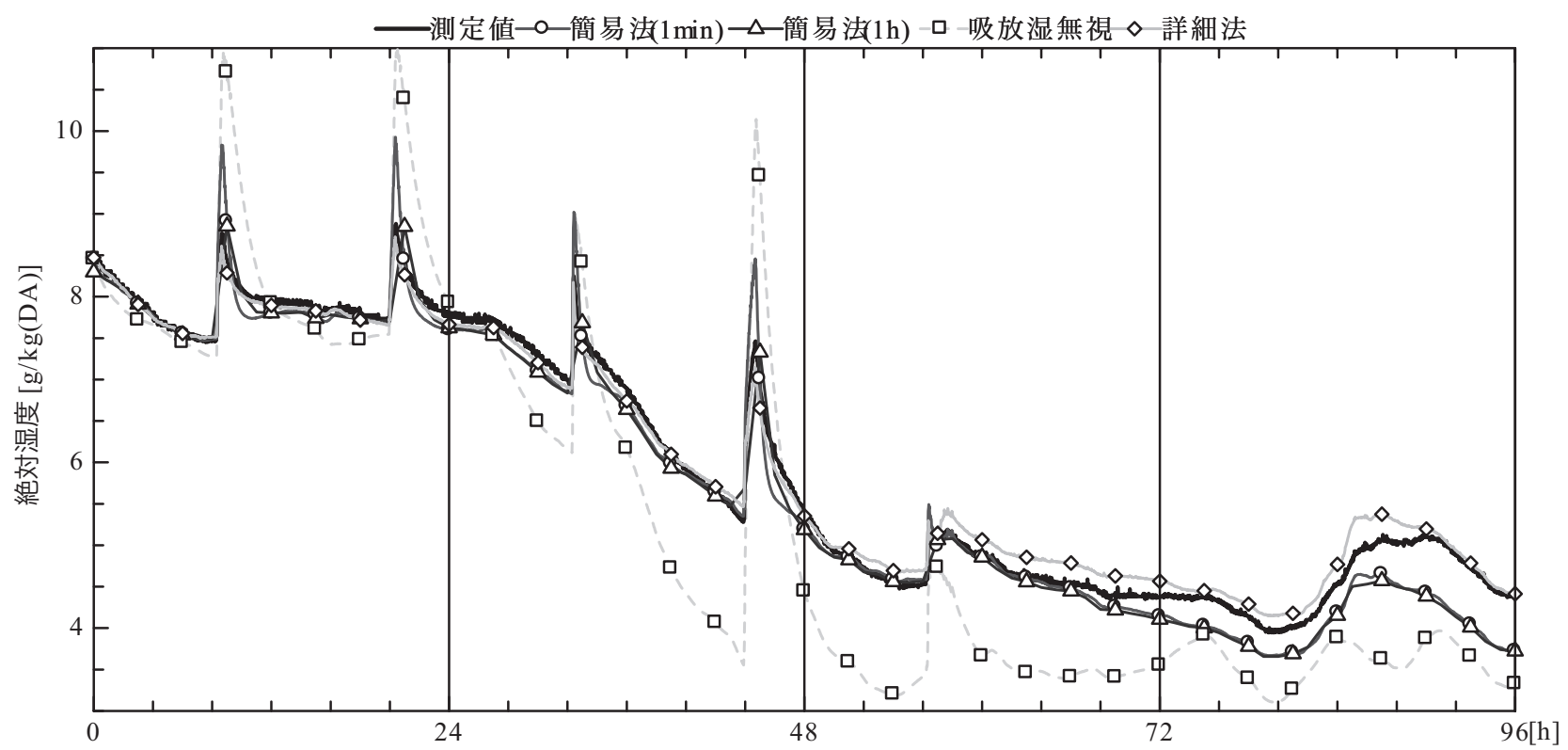

図 11 計算值と測定值の比較（絶対湿度）

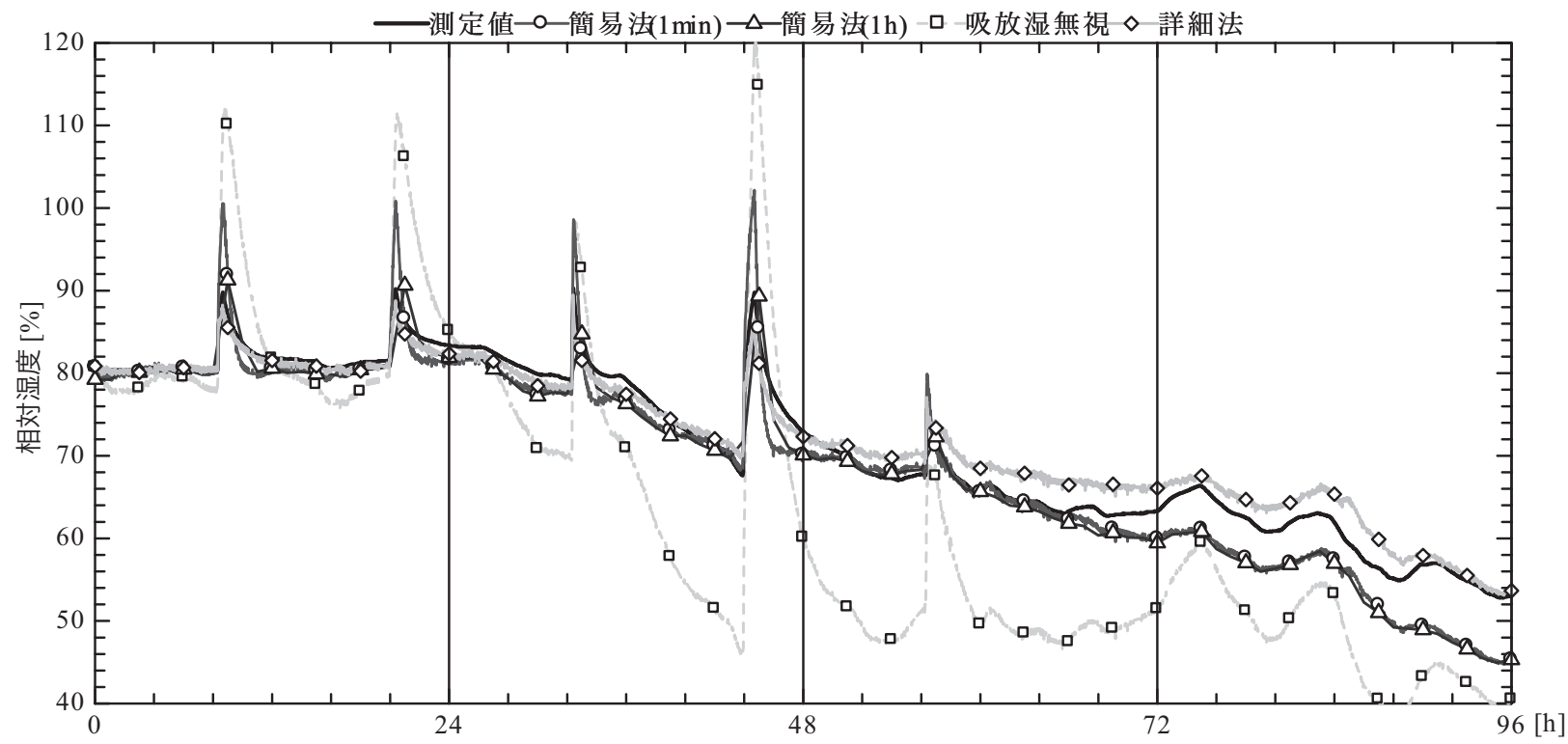

図 12 計算値と測定值の比較（相対湿度）

\section{4. おわりに}

本論文は，既報で提案した壁体吸放湿の簡易計算法を用いた室内 湿度変動モデルとその計算方法について述べた。また，バーミキュ ライト建材を設置した実験家屋居室内の湿度変動を測定し，測定值 と実験家屋居室に室内湿度変動モデルを適用した計算值の比較によ り計算精度を確認した。実験は, 除湿器や加湿器の運転開始時のよ うな, 室内湿度が突変する状況を想定したものであり, 実験家屋居 室内を加湿器により定期的に加湿した。

簡易法により壁体吸放湿を考慮することで，十分な精度で室内湿 度予測が可能であることを示した。ただし, 室内湿度の突変前後の 過渡応答や，長期に渡り室内湿度が高湿度あるいは低湿度になった
場合には詳細法に比べ予測精度は劣る。

簡易法は, 詳細法で解が得られなかった計算時間間隔 1 時間でも, 測定值との根平均二乗誤差と最大絶対誤差は, 相対湿度で $3.5 \% \mathrm{RH}$, $8.5 \% \mathrm{RH}$ ，絶対湿度で $0.29 \mathrm{~g} / \mathrm{kg}(\mathrm{DA}) ， 0.76 \mathrm{~g} / \mathrm{kg}(\mathrm{DA})$ の精度で予測結果 が得られた。

簡易法は，計算時間間隔 1 時間でも加湿などにより室内湿度変動 が突変した場合でも安定した解が得られること, 詳細法よりも計算 負荷が小さいことから, 通年の室内温湿度環境解析やエネルギー消 費量計算に向いた計算法と言える。また，計算時間間隔が小さい場 合も，比較的緩やかな湿度変動下での室内湿度予測であれば，十分 な精度が得られる。 
建材の物性值測定について, 京都府立大学の尾崎明仁教授よりご

\section{記号}

$c$ : 固体の比熱

$c_{p}:$ 気体の定圧比熱

$G$ : 重量流量

$h$ : エンタルピー

$I$ : 室の総数

$J$ : 室内表面の総数

$k$ : 水分ポテンシャル勾配

$L:$ 水分容量層の厚さ

$M$ : 水分伝導層の厚さ

$m:$ 分子量

$p$ : 圧力

$q_{r}$ ：放射熱収支量

$R$ : 気体定数

$r$ : 細孔半径

$S$ : 表面積

$S P$ : 単位面積当たりの吸放湿量

$s$ : エントロピー

$T$ : 絶対温度

$t$ : 時間

$V$ : 容積

$v$ : 単位質量当たりの細孔容積

$W$ : 室内水蒸気発生量

$X$ : 絶対湿度

$X$ : 空間座標

$\alpha_{c}$ : 対流熱伝達率

$\alpha^{\prime}$ : 水分ポテンシャル基準の水分伝達率

$\alpha_{X}^{\prime}$ : 絶対湿度基準の水分伝達率

$\lambda:$ 熱伝導率

$\lambda^{\prime}:$ 水分ポテンシャル基準の気相水分伝導率

$\theta$ : 接触角

$\mu_{w}:$ 水分ポテンシャル

$\mu$ : 不飽和水分ポテンシャル

$\mu_{w}^{0}:$ 飽和水分ポテンシャル

$\rho$ : 密度

$\sigma$ : 表面張力

$\phi$ : 容積基準容積含水率

\section{添字}

$a$ : 乾き空気

$a c$ : 空調機

$i$ : 室内空気

$i j$ : 隣室空気

$j$ : 室内表面

$l$ : 水分容量層内部

$l w$ : 液水

$m$ : 湿り空気
$[\mathrm{J} /(\mathrm{kg} \cdot \mathrm{K})]$

$[\mathrm{J} /(\mathrm{kg} \cdot \mathrm{K})]$

$[\mathrm{kg} / \mathrm{s}]$

$[\mathrm{J} / \mathrm{kg}]$

$[\mathrm{J} /(\mathrm{kg} \cdot \mathrm{m})]$

[m]

[m]

$[\mathrm{kg} / \mathrm{mol}]$

[Pa]

$\left[\mathrm{J} / \mathrm{m}^{2}\right]$

$[\mathrm{J} /(\mathrm{kg} \cdot \mathrm{K})]$

[m]

$\left[\mathrm{m}^{2}\right]$

$\left[\mathrm{kg} /\left(\mathrm{m}^{2} \cdot \mathrm{s}\right)\right]$

$[\mathrm{J} /(\mathrm{kg} \cdot \mathrm{K})]$

[K]

[s]

$\left[\mathrm{m}^{3}\right]$

$\left[\mathrm{m}^{3} / \mathrm{kg}\right]$

[kg/s]

[kg/kg(DA)]

[m]

$\left[\mathrm{W} /\left(\mathrm{m}^{2} \cdot \mathrm{K}\right)\right]$

$\left[\mathrm{kg} /\left(\mathrm{m}^{2} \cdot \mathrm{s} \cdot(\mathrm{J} / \mathrm{kg})\right)\right]$

$\left[\mathrm{kg} /\left(\mathrm{m}^{2} \cdot \mathrm{s} \cdot(\mathrm{kg} / \mathrm{kg}(\mathrm{DA}))\right)\right]$

$[\mathrm{W} /(\mathrm{m} \cdot \mathrm{K})]$

$[\mathrm{kg} /(\mathrm{m} \cdot \mathrm{s} \cdot(\mathrm{J} / \mathrm{kg}))]$

$\left.{ }^{\circ}\right]$

$[\mathrm{J} / \mathrm{kg}]$

$[\mathrm{J} / \mathrm{kg}]$

$[\mathrm{J} / \mathrm{kg}]$

$\left[\mathrm{kg} / \mathrm{m}^{3}\right]$

$[\mathrm{N} / \mathrm{m}]$

$\left[\mathrm{kg} / \mathrm{m}^{3}\right]$
注

注1）既報では「変曲点の位置」と称したが，表現が不適切であると考え， 「水分伝導層の厚み」と表現を改める。

注2) 既報の式(3)において，水蒸気圧を絶対湿度に変換すれば，不飽和水分 ポテンシャルと絶対湿度の関係が得られる。この関係が非線形関係で あるため，既報の式(1)で定義される水分ポテンシャルも絶対湿度と非 線形関係となる。

注3）既報では水分容量を $\partial \phi / \partial \mu$ と記述したが， $\rho_{l w} \partial \phi / \partial \mu$ 誤りである。したが つて, 式(22), (23), (25), (26)の記述も詋りである。ここに訂正する。 上記式中の数值や計算結果は変わらない。

参考文献

1）例えば，SMASH for Windows（住宅用熱負荷計算プログラム）ユーザーマ ニュアル：財団法人 建築環境・省エネルギー機構，pp.107，1999

2) 松尾陽，永田明寛：吸放湿を考慮した熱負荷計算法，第 21 回熱シンポジ ウム, pp.55-64, 1991.8

3) 吉田治典，寺井俊夫，末吉弘明：多層壁の熱・水分同時移動における三 角波応答の離散フーリエ変換による計算法, 空気調和・衛生工学会論文 集 No.46, pp.21〜30, 1991.6

4) 宿谷昌則，斉藤正文：熱・水分容量質点系モデルを用いた室内温湿度の 簡易シミュレーション, 日本建築学会学術講演梗概集, pp.921-922, 1987.10

5) 芝池英樹, 松本衛 : 境界要素法による多層平面壁の非定常熱・湿気性状 の解析とその非線形性の検討，日本建築学会計画系論文報告集 No.366, pp22 32, 1986.8

6) 土屋喬雄 : 戸建て住宅の換気と室内温湿度, 空気調和・衛生工学, Vol.54 No.11, pp.13-19, 1980.11

7) 木村建一：建築環境学 2, 丸善, 1993

8）細川隆行，林徹夫，尾崎明仁，小島昌一，野村幸司：水分ポテンシャル に基づく壁体内表面における吸放湿の簡易計算法の提案 多数室温湿度 計算への適用を目的とした室内表面の吸放湿計算モデル その2, 日本建 築学会環境系論文集，No.573，pp.47-53，2003

9) Akihito Ozaki, Toshiyuki Watanabe, Tetsuo Hayashi and Yuji Ryu : Systematic analysis on combined heat and water transfer through porous materials based on thermodynamic energy, Energy and Buildings, Volume 33, Issue 4, pp. 341-350, April 2001

10) 尾崎明仁, 香川治美 : 多孔質材料の熱・物質移動の駆動力と拡散係数の 関係について, IBPSA-Japan 講演論文集 (Technical Papers of Annual Meeting of IBPSA-Japan)， 2007

11) 空気調和衛生工学会規格: SHASE-S 116-2003 トレーサガスを用いた単一 空間の換気量測定法，2003 年

12) JIS A 1324 ：建築材料の透湿性測定方法，1995 年

13) 例えば, 近藤精一, 石川達雄, 阿部郁夫 : 吸着の化学 第 2 版, 丸善, 2001 